\title{
THE PROJECT OF THE SELF-ASSESSMENT DESCRIPTORS FOR CZECH AS A SECOND LANGUAGE
}

\author{
KATEŘINA ŠORMOVÁ \\ Charles University,

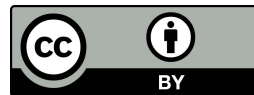 \\ Institute of Czech Language and Theory of Communication, Faculty of Arts \\ nám. Jana Palacha 2, 11638 Prague 1, Czech Republic \\ E-mail address: katerina.sormova@gmail.com
}

\begin{abstract}
Aim. The aim of the research is to evaluate the set of the self-assessment descriptors for Czech as a second language.

Methods. The subject of the study were 753 descriptors evaluated by 50 teachers and 640 students. They are analysed with the application od questionaires and controlled interviews. Pilot project tested the methodology to estabilish the difficulty level of descriptors and the ability level of learners.

Results. The analysis shows that some of the descriptors need to be reduced and some of them reformulated.

Conclusion. The analysis shows that many teachers are not sufficiently informed on Czech as a second language, they evaluate the descriptors from the perspective of a foreign language. Another finding is the inexperience of many teachers with the language levels following the CEFR; they label words or grammatical elements as an inappropriate level, but their estimate is very often incorrect. The teachers mark sayings, proverbs and idioms as the most problematic. The students are often able to express the given meaning, but they are shy to speak in a foreign language.

Key words: Czech as a second language, self-assessment, descriptor, pilot study,
\end{abstract} CEFR

The issue of self-assessment is not yet an automatic part of language teaching. One of the pioneering projects in this area is the European Language Portfolio, which consists of three parts (Language Passport, Language Biography and Dossier). Part of the Language Biography are self-assessment descriptors that continually record the student's progress in that language.

One of the effects of self-assessment is the encouragement of students in setting academic, professional and personal goals. As presented by Sharma, Naveenta Gupta, Garg, Batta, and Kant Dhir (Sharma, Naveenta Gupta, Garg, Batta, \& Kant Dhir, 2016, p. 226): "Self-assessment can increase the interest and motivation level of students for the subjects leading to enhanced learning and 
better academic performance, helping them in development of critical skills for analysis of their own work."

In our article, we will introduce a project for the creation of self-assessment descriptors for Czech as a second language, which is being developed by the National Institute of Education in Prague.

\section{THE ISSUE OF CZECH AS A SECOND LANGUAGE}

The self-assessment descriptors of the European Language Portfolio are suitable for the students who study a given language as a foreign language, but the situation of the users of Czech as a second language is different. The Czech Statistical Office (The Czech Statistical Office) states that in 2016, 493,000 foreigners lived in the CR based on permanent or long-term residence. In the school year 2015/2016, more than 86,000 foreigners studied at all types of schools, of which more than 18,000 at basic schools (primary education) and more than 42,000 at higher education institutes. As Janovec and Rangelová state (Janovec, \& Rangelová, 2006) the broadly conceived integration process includes a number of social, economic, general-cultural and psychological factors. From the perspective of linguistics, acquisition of the majority language seems to be the most important process, implying the achievement of a certain linguistic competence allowing the individual a successful realisation in the foreign-language milieu. In this process, a certain specific form of bilingualism is achieved in a relatively short time, which is characterized by an imbalance of the knowledge of Czech in its function-style stratification: the spoken language has the primary position, the degree of acquisition of written Czech is negligible with almost half of the respondents and the vast majority speak of linguistic difficulties in official relations, especially in written speeches (Janovec, \& Rangelová, 2006). These foreigners have Czech in the position of not a foreign but a second language. The position of a second language is predominantly given by its importance in the life of a person; it is a language on which the user is existentially dependent. In children, it is the language of integration into school attendance; in adults it is the language that makes it possible to integrate into the social majority, so it is the language that is necessary for working in a given society.

\section{THE SPECIFIC NATURE OF THE ACQUISITION OF CZECH AS A SECOND LANGUAGE}

The level of the acquisition of Czech is usually very different and depends on the individual language skills; the different needs of the students appear mainly in the area of socio-cultural competence and the different psychological relations between the student and the language. It is particularly the issue of a forced language (hence a language which the student has not chosen freely based on his/her interest). As Cvejnová stated (Cvejnová, 2016), in instruction, it is at first mainly the instruction of compensation strategies and basic lingu- 
istic functions (greetings, thanking, a request...). In the first phase, instruction of speaking and listening prevails over the instruction of reading and writing and the instruction of the basic lexis over the instruction of grammar.

\section{SELF-ASSESSMENT IN THE DIDACTICS OF A LANGUAGE}

One of the important aspects in learning a foreign language is the ability of self-assessment. In the case of school instruction, self-assessment should become an integral component of teaching, where it should be a part of further discussion and work in class. It should be complemented by the assessment of the teacher or lecturer. Self-assessment helps pupils/students to become aware of their strengths and weaknesses and to regulate their further learning in an appropriate way. The evaluation of the teachers has a control importance for the pupil/student; it can also be motivational. The self-assessment descriptors encompass the descriptors of the specific skills which correspond to a given level according to the CEFR. The descriptors form a uniform scale and are formulated clearly, concisely and positively (the goal is to name what the student knows how to do, not what he/she does not know how to do). The self-assessment descriptors can be used in various ways. Primarily for monitoring what advancements a given student is making in his/her study, but secondarily also for setting the teaching goals for the entire class and for harmonizing work with the textbook and with the European Language Portfolio (ELP).

\section{DESCRIPTORS FOR CZECH AS A SECOND LANGUAGE}

The creation of the descriptors for Czech as a second language is implemented by the National Institute for Education, a ten-member team of linguists and language lecturers engaged in the project. The project's aim is the support of Czech as a second language both in the area of the education of minors and also adult migrants. The notion of self-assessment arises from the descriptors for foreign languages of the European Language Portfolio (Little, \& Perclová, 2001; Common European Framework of Reference for Languages, how we teach them and how we evaluate them in languages, 2002). The descriptors are intended exclusively for the self-assessment of the students; they are not a testing instrument. With lower levels and younger age groups, the help of the teacher is expected, with higher levels and older age categories the student should be capable of assessment independently. As Brychová, Janíková and Sladkovská state (Brychová, Janíková, \& Sladkovská, 2012) the aims of the European Language Portfolio are particularly these four: (1) to record the advancement of the student, (2) to record the method through which the student learns a language/s, (3) to record which languages the student knows and (4) to record what the student knows and knows how to do. Recording of the advancement of the student takes place continually and the self-assessment descriptors serve for precisely that. 


\section{THE NOTION OF THE CREATION OF THE DESCRIPTORS}

1. The project lasted from June 2016 to January 2018. The creation of the descriptors was divided into four phases:

a. analysis of existing descriptors from the ELP and other foreign projects,

b. reformulation of existing descriptors and creation of new descriptors with respect to the users of Czech as the second language,

c. piloting of the descriptors,

d. processing the results of the piloting and final formulation of the descriptors.

In the initial analysis of the descriptors, three sources were mainly used (1) the existing general descriptors from the ELP, (2) the reference description of the Czech language for the purposes of the examination for permanent residency, and (3) foreign portfolios and projects.

For the creation of new descriptors, four age categories and four levels of advancement were established (Table 1).

Table 1. Age categories.

\begin{tabular}{lll}
\hline & Age category & Language level \\
\hline \multirow{3}{*}{ children } & up to age 11 & $\mathrm{A} 1, \mathrm{~A} 2, \mathrm{~B} 1$ \\
\cline { 2 - 3 } & $11-15$ years & $\mathrm{A} 1, \mathrm{~A} 2, \mathrm{~B} 1$ \\
\hline \multirow{3}{*}{ adults } & $15-19$ years & $\mathrm{A} 1, \mathrm{~A} 2, \mathrm{~B} 1, \mathrm{~B} 2$ \\
\cline { 2 - 3 } & $19+$ years & $\mathrm{A} 1, \mathrm{~A} 2, \mathrm{~B} 1, \mathrm{~B} 2$ \\
\hline
\end{tabular}

Source: Author's own work.

Each descriptor consists of four parts - the label of the level and skill, the body of the descriptor, the example and the options of the opportunities for self-assessment (Table 2).

Table 2. Composition of the descriptor.

\begin{tabular}{|c|c|c|c|}
\hline \multicolumn{2}{|r|}{ Age category } & \multicolumn{2}{|c|}{ Language level } \\
\hline & up to age 11 & \multicolumn{2}{|c|}{$\mathrm{A} 1, \mathrm{~A} 2, \mathrm{~B} 1$} \\
\hline \multirow[t]{2}{*}{ children } & $11-15$ years & \multicolumn{2}{|c|}{$A 1, A 2, B 1$} \\
\hline & 15-19 years & \multicolumn{2}{|c|}{$\mathrm{A} 1, \mathrm{~A} 2, \mathrm{~B} 1, \mathrm{~B} 2$} \\
\hline adults & $19+$ years & \multicolumn{2}{|c|}{$\mathrm{A} 1, \mathrm{~A} 2, \mathrm{~B} 1, \mathrm{~B} 2$} \\
\hline Writing A1 & $\begin{array}{l}\text { I understand what I have to } \\
\text { write in the form. }\end{array}$ & $\begin{array}{l}\text { Name, surname, } \\
\text { residential address, } \\
\text { employment. }\end{array}$ & $\begin{array}{l}\text { Yes. } \\
\text { A little. } \\
\text { Not yet. }\end{array}$ \\
\hline Reading B1 & $\begin{array}{l}\text { I undertsand the texts, which } \\
\text { describe the method (how to } \\
\text { do something) in textbooks. }\end{array}$ & $\begin{array}{l}\text { How I am to calculate } \\
\text { the example. How I am } \\
\text { to prepare a project for } \\
\text { an hour of English. }\end{array}$ & $\begin{array}{l}\text { Yes. } \\
\text { A little. } \\
\text { Not yet. }\end{array}$ \\
\hline
\end{tabular}

Source: Author's own work.

The descriptors vary not only by age but also by the language level for which they are intended. The descriptors for the age category 15-19 years are depicted in the table (Table 3). 
Journal of Education Culture and Society No. 1_2018

Table 3. Descriptors for the age category 15-19 years.

\begin{tabular}{|c|c|c|c|}
\hline $\begin{array}{l}\text { Skill and } \\
\text { level }\end{array}$ & Body of the descriptor & Example & $\begin{array}{l}\text { Self- } \\
\text { assessment }\end{array}$ \\
\hline Reading A1 & $\begin{array}{l}\text { I understand when I see } \\
\text { next to a known word } \\
\text { numbers, names or }\end{array}$ & $\begin{array}{l}\text { 2nd floor. } \\
3 \text { tickets. }\end{array}$ & $\begin{array}{l}\text { Yes. } \\
\text { A little. } \\
\text { Not yet. }\end{array}$ \\
\hline Reading A2 & $\begin{array}{l}\text { I understand a short text } \\
\text { on what interests me. }\end{array}$ & $\begin{array}{l}\text { Short letter or e-mail, short } \\
\text { messages. }\end{array}$ & $\begin{array}{l}\text { Yes. } \\
\text { A little. } \\
\text { Not yet. }\end{array}$ \\
\hline Reading B1 & $\begin{array}{l}\text { I understand texts which } \\
\text { describe a method (how } \\
\text { to do something) in } \\
\text { textbooks. }\end{array}$ & $\begin{array}{l}\text { How I am to calculate a } \\
\text { quadratic equation, how I } \\
\text { am to process a laboratory } \\
\text { protocol from chemistry, } \\
\text { how I am to prepare a } \\
\text { project for English }\end{array}$ & $\begin{array}{l}\text { Yes. } \\
\text { A little. } \\
\text { Not yet. }\end{array}$ \\
\hline Reading B2 & $\begin{array}{l}\text { I know how to quickly } \\
\text { understand the content } \\
\text { of articles, which } \\
\text { concern my interests or } \\
\text { the field of my studies. I } \\
\text { know how to find out if I } \\
\text { need to read them or }\end{array}$ & & $\begin{array}{l}\text { Yes. } \\
\text { A little. } \\
\text { Not yet. }\end{array}$ \\
\hline
\end{tabular}

Source: Author's own work.

In the individual skills, three types of descriptors appear, descriptors aimed at general skills, specialized descriptors (focused on the school or work milieu) and compensation strategy. An example of the compensation strategies is provided in the subsequent table (Table 4).

Table 4. Compensation strategies.

\begin{tabular}{|c|c|c|}
\hline Skill and level & Body of the descriptor & Self-assessment \\
\hline Reading B1 & $\begin{array}{l}\text { I know how to underline } \\
\text { the parts in the text that I } \\
\text { do not understand. }\end{array}$ & $\begin{array}{l}\text { Yes. } \\
\text { A little. } \\
\text { Not yet. }\end{array}$ \\
\hline Writing A1 & $\begin{array}{l}\text { When I write, I use } \\
\text { previously learned phases } \\
\text { or a dictionary. }\end{array}$ & $\begin{array}{l}\text { Yes. } \\
\text { A little. } \\
\text { Not yet. }\end{array}$ \\
\hline Speaking A1 & $\begin{array}{l}\text { I know how to say that I } \\
\text { need something repeated. }\end{array}$ & $\begin{array}{l}\text { Yes. } \\
\text { A little. } \\
\text { Not yet. }\end{array}$ \\
\hline Listening B2 & $\begin{array}{l}\text { When listenings are hard } \\
\text { for me, I focus on the main } \\
\text { points. }\end{array}$ & $\begin{array}{l}\text { Yes. } \\
\text { A little. } \\
\text { Not yet. }\end{array}$ \\
\hline
\end{tabular}

Source: Author's own work. 
2. The notion of the piloting of the descriptors

The piloting of the descriptors took place from September to December 2017 and was done in order to verify the formulations of the descriptors and their comprehensibility for the target group. The piloting had two phases - in the first phase a language diagnostic was conducted, on the basis of which the language level of the engaged foreigners was set; in the second phase the descriptors were tested; this testing took place in cooperation with the teachers.

The aim of the piloting was to verify (1) whether the descriptors correspond to the given language level and (2) whether the descriptors are comprehensible for the individual language levels and whether they reflect the life reality of the target group.

The questionnaires were broken down by age and language level, students filled in their questionnaires in each class, and the teacher filled in a questionnaire based on the observation of the students and based on their own pedagogical experience. The teachers also filled in their own commentaries in the questionnaire, which were the most important result of the piloting.

\section{Research design}

The selection of the sample took place using a stratified sampling; pupils and teachers from primary, secondary and tertiary schools were included in the piloting and also language schools were included.

Children and adults for whom Czech is a second language fell into the selected sample of foreigners; for instance, Roma or Slovaks did not fall into our target group because the process of accepting Czech is usually different with them. In the case of the Slovaks, the kinship of the languages is so close that it would have influenced the piloting, in the case of the Roma it can be justifiably assumed that they usually speak a Roma ethnolect of Czech, which bears the structural specificity of Slovak, Roma and Hungarian. For them, Czech is not usually a second language but a first. Pupils from the $3^{\text {rd }}$ Form (inclusively), hence from age 9, with whom elementary literacy is already developed and who know how to read and write in the Latin alphabet, were included in the piloting.

A total of 35 schools and more than 50 teachers were involved in the piloting, who were responsible for testing the pupils and then evaluation of the questionnaires with the descriptors. The total number of pupils tested was greater than 640. In Table 5, we see the distribution of the number of students at individual levels. According to our expectation, it was confirmed that the low language levels of A2 and A1 are also prevalent in the low age category (up to age 11). It is caused by two factors; the first is the short time of their stay in the Czech Republic, the second is the level of the cognitive abilities of children in the given age (a child at age 10 cannot read at level B2 even in their mother tongue, because they do not have a sufficient level of developed reading skills), but level A2 predominated also in another two age categories (15-19 years and 19+). We judge from that that in the case of adult respondents it is a category which Czech is most often learned institutionally; the higher categories apparently continue more commonly in private courses or the language is not learned systematically. 
Table 5. Number of descriptors

\begin{tabular}{lcccc}
\hline & A1 & A2 & B1 & B2 \\
\hline to age 11 & 26 & 47 & 2 & \\
\hline $11-15$ years & 8 & 21 & 37 & 51 \\
\hline $15-19$ years & 40 & 71 & 44 & 28 \\
\hline $19+$ & 52 & 168 & 45 & \\
\hline
\end{tabular}

Source: Author's own work.

4. The results of the piloting and the conclusions

The total number of the tested descriptors was 753, its division according to skills is shown in Table 6 . The speaking skill shows a distinctly higher number of descriptors, which is caused by the fact that speaking has two more subcategories - the first aimed at independent oral speech and the second aimed at oral interaction with a communication partner.

Table 6. Distribution of descriptors

\begin{tabular}{lllll}
\hline & A1 & A2 & B1 & B2 \\
\hline reading & 46 & 44 & 38 & 18 \\
\hline writing & 53 & 49 & 45 & 27 \\
\hline listening & 58 & 56 & 56 & 23 \\
\hline speaking & 72 & 64 & 62 & 42 \\
\hline
\end{tabular}

Source: Author's own work.

The goal is to finish processing approximately half of the piloted descriptors into their final form and publish them on our website. At the time of the writing of this article, the results of the piloting were still not definitively evaluated; despite that, we can in this phase observe several tendencies.

a. Most commentaries by the teachers (approximately $70 \%$ ) monitor the language level, especially on the lexical level. It shows that many teachers are not sufficiently informed in Czech as a second language, they evaluate the descriptors from the perspective of a foreign language. The vocabulary of a second language is distinctly deeper and more specific than that of a foreign language, specialised phrases from many areas appear (health condition, communication with offices, communication with the school, social life).

b. Some commentaries of the teachers suggest the use of synonymous phrases, thanks to which the formulations of the descriptors will be simpler and clearer.

c. Another finding is the inexperience of many teachers with the language levels following the CEFR; they label words or grammatical elements at an inappropriate level, but their estimate is very often incorrect.

d. The teachers marked the descriptors which contain facts not related with the life experiences of their students (e.g. young students who are still studying do not have experience from a work environment). An interesting and repeated finding is the fact that students do not use dictionaries. 
e. In several cases, the teachers describe that the descriptors are similar in meaning and thus are duplicated.

f. Some examples are evaluated as misleading and recommended for reformulation.

g. The teachers mark sayings, proverbs and idioms as the most problematic.

h. An interesting comment is that students are often able to express the given meaning, but they are too shy to speak in a foreign language.

i. The teachers consistently state that there is usually a significant difference between the level reached in listening versus speaking, as well as reading versus writing.

\section{REFERENCES}

1. Brychová, A., Janíková, V., \& Sladkovská, K. (2012). Evropské jazykové portfolio v praxi [The European Language Portfolio in Practice]. Praha: NÚV. Retrieved from: http://elp.ecml.at/ LinkClick.aspx?fileticket=aKwqQUzIr8s\%3D\&tabid=2844\&language $=$ en-GB.

2. Cvejnová, J. (Ed.). (2016). Referenční popis češtiny pro účely zkoušky z českého jazyka pro trvalý pobyt $v \check{C} R$ - úrovne $A 1, A 2$ [Reference description of Czech for the purposes of the examination of the Czech language for permanent residence in the CR - Levels A1, A2]. Praha: Národní ústav pro vzdělávání. Retrieved from: http://www.nuv.cz/uploads/Publikace/ referencni_popis_08122016.pdf.

3. Janovec, L., \& Rangelová, A. (2006). Language integration of members of minorities. Lidé města, (8)1, 140-156. Retrieved from: http:/ /lidemesta.cz/archiv/cisla/8-2006-1/recova-integrace-prislusniku-minorit.html.

4. Little, D., \& Perclová, R. (2001). European Language Portfolio. Guide for Teachers and Teacher Trainers. [European Language Portfolio. Guide for Teachers and Teacher Trainers]. Strasbourg: Council of Europe, Modern Languages Division.

5. Sharma R., Jain A., Gupta N., Garg S., Batta M., \& Dhir Shashi K. (2016). Impact of self-assessment by students on their learning. International Journal of Applied and Basic Medical Research, (6) 3, 226-229.

6. Společný evropský referenční rámec pro jazyky - jak se učme jazykům, jak je vyučujeme a jak v jazycích hodnotíme [Common European Framework of Reference for Languages, how we teach them and how we evaluate them in languages]. (2002). Olomouc: Univerzita Palackého.

7. The Czech Statistical Office. Data - počet cizinců. Retrieved December 9, 2017, from https:// www.czso.cz/csu/cizinci/4-ciz_pocet_cizincu\#cr. 